\title{
INNOVATION OF TRAINING METHODS TO MEET THE NEEDS OF UNIVERSITY STUDENTS UNDER "LEARNING CITIZEN" MODEL
}

\author{
Dr. Tran Quoc Hoan \\ Ho Chi Minh City University of Culture, 51 Quoc Huong Street, Thao Dien Ward, \\ District 2, Ho Chi Minh City,Vietnam;
}

\begin{abstract}
:
After reflecting on the situation, the paper focuses on analyzing the innovation of higher education methods to meet learners' needs under the "learning citizen" model in the context of approaching the Fourth Industrial Revolution, with many opportunities and challenges. The paper identifies that higher education innovation to meet learners' needs under the "learning citizen" model is an effective way to take care of people's spiritual and material life, which is an important contribution to build a learning society.
\end{abstract}

Keywords: university, citizen learning, social learning, university training methods

\section{Introduction}

Innovating the university training methods to meet the needs of learners under the model of "learning citizen" is an objective and urgent requirement in the current national construction and development.

Over the past 30 years of reform, although Vietnam's higher education has made great strides, proudly contributing to the cause of building and defending the country, in the process of development, Vietnamese university training methods still have many shortcomings, not meeting the requirements of socio-economic development and international integration, especially training methods, which don't meet the needs of university students according to the model of "learning citizen", lack the scope of critical thinking and do not escape the limits of closed education.

In general, Vietnam's university training methods have not been able to reach the goal of training "learning citizens" with 7 basic requirements: 1). Critical thinking capacity; 2). Creative capacity in activities; 3). Capacity to use digital technology; 4). Foreign language ability; 5). A sense of lifelong learning; 6). Self-study capacity; 7). Consciousness contributes a lot to society (Pham Tat Dong, 2019).

\section{Document review and research methods}

Innovating the university training method to meet the needs of learners in the model of "learning citizen", which has been studied by domestic and foreign scholars from many different angles. 
Jacques Delors (1996) with the work Learning: The treasure within emphasized the lifelong learning process to contribute to community development, social renewal and self-renewal.

Donal Alan Schon (1973) introduced the concept "The Learning Society", in which people will learn for life. The problem that D.A. Schon emphasizes that "learning must be effective in every community". In each community, every citizen must have the opportunity to participate in learning in appropriate forms, so that at any time, place, they can learn, become "learning citizen".

Turten Husen (USA) emphasized the importance of "learning citizen" and said that education must create all the conditions for the continuous learning of people, that is an important factor to adapting to a rapidly changing society (Hunsen. T, 1974).

Besides, a number of other authors also proposed the innovation of university training methods to meet the needs of learners according to the "learning citizen" model, scattered in the works: Charles C. Bonwell and James A. Eison with Active Learning (Charles C. Bonwell and James A. Eison - 1991); David E. McNabb with Research Methods for Political Science (David E. McNabb, 2009); Knottnerus, J. David and Guan, Jian with research in Analytical Strategies, Developments and Assumptions (Knottnerus, J. David \& Guan, Jian, 1997); Tobias Andersson with Rationality in educational choice A study on decision-making and risk-taking in academic settings (Tobias Andersson, 2016); David R. Shans, Riachard J. Suney and John D. McCarthy with A retest of Probability and reasonable choice, Journal of behavioral decision making (David R. Shans, Riachard J. Duney and John D. McCarthy, 2002); Donatella della Porta, Michael Keat with Approaches and Methodologies in the Social Sciences (Donatella della Porta, Michael Keat, 2008).

In Vietnam, in the process of implementing the policy of building "learning society", "learning citizens", from 2000 to now, there have been many research projects related to the topic Innovating modern training methods to meet the needs of learners according to the model of "learning citizen" of authors Dang $\mathrm{Huu}, \mathrm{Vu}$ Dinh $\mathrm{Cu}$, Chu Tuan Nha, Chu Hao, Phan Dinh Dieu, Pham Tat Dong, Dang Ngoc Dinh, Tran Viet Phuong, Vo Dai Luoc, Nguyen Quang Thai, Tran Dinh Thien ... Among them, the author Pham Tat Dong has quite a lot of research works on "learning citizens" and "learning society" such as building people, building learning society; Towards a learning society (Pham Tat Dong, 2011), Building a learning society model in Vietnam (Pham Tat Dong, 2012).

Most of the researches and programs on renovating university training methods to meet the needs of learners under the model of "learning citizen" aim to train individuals with the ability to think critically and brightly. Create in operations, use digital technology, foreign languages, have a sense of lifelong learning, contribute an important step to development whether in science, experiment or purely theory, in business management or state, whether local, national or international.

In this study, the author approaches in the direction of interdisciplinary and multidisciplinary; approach from the systematic point of view, the historical point of view. Regarding research methods, the author combines the research methods of the science of History, Geography and Anthropology, and Sociology, including the method of collecting, analyzing and synthesizing documents; survey method; Statistical methods; quick assessment method. 


\section{Research results and discussion}

\subsection{The situation of university training meets the needs of learners according to the current "learning citizen" model in Vietnam}

"Learning citizen" is the core element of "learning society" which is a society in which everyone can learn, need to learn and self-study regularly, learning for life. Since 2005, the Prime Minister has approved the project "Building a learning society in the period 2005 - 2010" with the general criterion of creating opportunities and favorable conditions for people of all ages, all levels to be able to study regularly, learn continuously, learn for a lifetime at anytime, anywhere, at all levels; mobilize the aggregate strength of the whole society to participate in education construction and development. Everyone, every organization has responsibility and obligation in learning and actively participates in building a learning society.

The model of "learning citizen" in higher education in Vietnam is oriented towards the necessary values, which must ensure the quality and capacity requirements of citizens studying. Basic qualities: Legal awareness and observance of civic obligations; studious spirit, self-study will; spirit, ability to set up a career; labor consciousness, professional ethics; cooperative spirit; strong lifestyle. On the ability to master and develop themselves (self-study, critical thinking, initiative, creativity); capacity to use tools (calculation, information technology, foreign languages); capacity to implement social relations (communication and cooperation) (Pham Tat Dong, 2019).

After 15 years (2005 - 2020), the university training to meet the needs of learners in the model of "learning citizen" shows that this model has achieved important results, accelerating the campaign to build communes. Learning Association in Vietnam approaches the trend of educational development of the modern world. University training to meet the needs of learners according to the model of "learning citizens", equipping learners with knowledge, skills and techniques to meet the development requirements of society and in line with the general trend, greatly contributing to the cause of national construction and defense.

The development of higher education in Vietnam in the 2005-2020 period meets the needs of learners according to the "citizen learning" model expressed through innovative teaching methods, organizing training programs with the goal of providing give students knowledge on a par with top Asian universities. In universities that have had a lot of positive changes, faculty use active and student-focused teaching methods such as group work, presentations, self-study, practice in the lab more. Since 2007, the Ministry of Education and Training has changed from the unit-based training system to the credit system (120 credits). Students are increasingly encouraged to "self-study" and participate in scientific research.

However, besides these proud achievements, university training activities to meet the needs of learners under the "learning citizenship" model still has many limitations, especially training methods. If in the US, the traditional method of university teaching giving presentations - was still maintained "throughout the 1980 s,... the traditional teaching method in which professors spoke and students listen, dominate "in America (Charles C. Bonwell et al., 1991), in Vietnam today this method still "dominates" most universities.

Traditional teaching methods allow teachers to show and impart knowledge, aiming to make students understand and remember knowledge, but this method pays little 
attention to developing thinking, skills training and attitude training for learners, leading to the situation that most of the students who passively learn, graduate do not meet the job requirements well.

The major limitation of the presentation teaching method, the lecturers force students to listen, to think in the way of the teacher; faculty decide and students must follow; students have no choice. Rigid traditional teaching methods, teacher-centered, lectures based on curriculum.

The scientific basis of traditional teaching methods is that when information and knowledge reach the learners' brains, they are converted and stored in memory, then the information can then be retrieved when needed. In practice, there are still teachers who have applied the presentation method quite successfully. However, with traditional teaching methods in which mainly teachers speak - students listen; teachers read students copy; teachers shows on screen - students copy has revealed a number of limitations: not encouraging the active role of learners; learners often passively affect their learning ability and concentration; discourage multidimensional information exchange; Lecturers communicate one-way, uncontrollable time that learners spend studying and deeply memorizing the content presented. In order to study well, learners must listen, take notes, try to remember to repeat the knowledge taught because the final exams, graduation often require recalling memory; Learners must use memory a lot, fatigue, stress, and pressure.

In most students and some university lecturers mentality still consider the university as a "general" level, still maintain one way of learning, teaching one-way knowledge transmission; learn "cramming"; "depending on" the curriculum, afraid of "not catch up with" the lesson plan. The teacher teaches "what a teacher has", regardless of whether the student "needs" or not; The learner is forced to "accept" - absolutely no choice. As a result, the quality of Vietnam's higher education is deteriorating, not enough conditions and ability to integrate into the regional and international labor market. It is difficult for a student graduating from university in Vietnam to work in countries with relatively high income such as Singapore, Japan, Germany... If students want to work in those countries, graduated students in Vietnam must learn more and update more with their knowledge and skills, it takes a lot of time, effort and money. Meanwhile, Vietnamese university graduates from these countries will be invited to work by organizations, including Vietnamese universities. This is one of the reasons why Vietnam's overseas study "trends" takes place strongly in the context that education is a product of society, and learners have the right to choose (Tobias Andersson, 2016).

Although the average cost for a year to study in the US is about 35,000 USD and to get a bachelor's degree students have to spend about 150 thousand USD, many Vietnamese students are still willing to pay, because they lack belief in higher education in the country. That leads to more and more students going abroad to study.

If we conceive that training is also a kind of service in which products are people who meet the requirements of highly qualified human resources of society, then clearly the product of training depends on many factors such as training programs, training environment, training of soft skills... but one of the most important things is the training method. In other words, in order to improve the quality of higher education in Vietnam, to meet the needs of learners according to the "learning citizen" model, one of the indispensable paths to go through is renewing the training method- this is a requirement of objective reality. Because "universities in Vietnam today generally do not have access 
to the world's popular methods and organizational forms of higher education" (Pham Cong Nhat, 2014); The application of teaching methods and forms of teaching organization of universities in the world is often very flexible, based on the spirit of promoting the role of learners, creating maximum conditions for learners to learn by themselves.

Current popular conception of Vietnamese universities is to equip learners with as much knowledge as possible so that they can have a solid foundation upon graduation, so the role and position of students are not are not really cared so much. Teaching methods and forms are still quite out of date. The results of a field survey by the US National Academy in 2006 commented on Vietnam's higher education methods as follows: teaching methods are ineffective, too dependent on presentations and less use of active learning skills, resulting in little interaction between students and faculty inside and outside the classroom; too much emphasis on memorization of knowledge without emphasis on conceptual learning or advanced learning (like analysis and synthesis), resulting in superficial rather than intensive learning; students learn passively.

The innovation of teaching methods in universities in Vietnam today is sometimes only superficial. Teaching facilities, such as projectors, videos ... are only aids to improve the quality of teaching, the most important thing is the realization that education must be creative and responsible. This is reflected in the lack of attention paid to methodology and curriculum improvements (Pham Cong Nhat, 2014). The quality of university training meets the needs of learners under the model of "learning citizen" but has not yet met the requirements of socio-economic development, many students lack understanding of cultural traditions, history, citizenship rights and obligations: foreign languages, informatics, ability to think independently, creatively, practice skills, and communication skills are still weak. The orientation and links with foreign countries in the higher education program are confusing, ambiguous, do not have clear goals and directions, so they have not attracted investment and cooperation from countries with developed advanced education in the world.

The above-mentioned fact does not fully and substantially reflect the current Vietnamese university training methods, but it is also a ringing reminder that we need immediate solutions to innovate the method of university training and meet the needs of learners under the model of "learning citizens", if not, they will lag further behind in comparison with other countries in the region and in the world.

\subsection{Innovating university training to meet the needs of learners under the model of "learning citizens"}

On November 4, 2013, the Eighth Conference of the XI Central Executive Committee approved Resolution No. 29 - NQ / TW on "innovating fundamentally and comprehensively of education and training, meeting requirements of industrialization and modernization in socialist-oriented market economy and international integration".

On the basis of summarizing educational and training activities in the innovation period, in which the activities of building a learning society, building the model of "learning citizen" and university training meet the needs of learners according to model of "learning citizens", Resolution No. 29 - NQ/TW, emphasizes innovation in university training activities to meet the needs of learners under the model of "learning citizens" to develop a learning society. And there, everyone has to learn to know, learn to do, learn to live together and learn to be human. Because each individual wants to survive and 
develop needs the opportunity and ability to continuously learn to master knowledge, to become knowledgeable citizens in life. "Learning citizen" becomes the essential need of everyone inside and outside the school, regardless of ethnicity, religion, social status, age, rich and poor... "learning citizen" is both a goal and a means of each individual in particular and the community in general. Building a learning society with the core "Learning Citizen" helps people form and develop personality, understand the values of life, understand their living environment and work to develop the degree, career skills and social communication.

In the spirit of Resolution No. 29 - NQ/TW, the contents and training programs need to be reformed in the direction of attaching importance to developing the quality of learners' competencies. Renovating educational content in the direction of streamlining, modern and practicality, suitable to age, level and profession; attach importance to the education of moral character, legal awareness and civic consciousness.

Therefore, the innovation of university training activities to meet the needs of learners according to the "learning citizenship" model is to innovate the content, the program must be conducted synchronously elements of education and training in the direction of attaching importance to the development of learners' qualities and capabilities. Innovation must ensure the systematic and suitable with the socio-economic conditions of the country. The Resolution of the Eighth Central Executive Committee Meeting Session XI stated:

"Fundamental and comprehensive innovation in education and training is to innovate big, core, urgent issues, from point of view, directing ideas to the goals, contents, methods, mechanisms, policies and conditions to ensure implementation, innovating from the Party's leadership, the State's management to the governance of the facilities education - training and participation of the family, community, society and learners themselves, innovating at all levels of study and disciplines. In the renewal process, it is necessary to inherit and promote achievements, develop new factors, selectively absorb world experiences; resolutely rectify perceptions, misleading jobs. The innovation must ensure the systematic, longterm vision, suitable to each type of object and level of education; solutions must be synchronous, feasible, with focus, focus, appropriate roadmap and steps" (Communist Party of Vietnam, 2011, p.119-120).

Higher education in Vietnam has stopped too long at an education that only focuses on specialized knowledge equipment. The undergraduate and postgraduate training programs are dense with knowledge. Exam activities highly recommend the memorization of professional knowledge. Therefore, the content innovation, the higher education and training program will contribute to overcoming the limitations that Vietnam's education is currently facing.

About teaching and learning methods in universities in Vietnam, there are many different understanding methods. Method is a way, a product created by human and also the subject of using the method, bringing the method into practical human activities, making the method possible to be effective. Teaching methods and activities have an organic relationship with each other, in the teaching process, teachers use methods to transmit knowledge to learners and the effectiveness of acquiring depends on the method of teaching. Today, when the amount of human knowledge is increasing very rapidly, the 
teacher cannot transmit all the knowledge to the learners. A good teacher must be someone who finds a method of stimulating learners so that they can conquer the knowledge they need. A good teacher must be someone who can mobilize the wisdom of the collective, making their students the center of the class.

Higher education is a special social phenomenon, a purposeful process, teachers must be responsible for their activities, learners are active, positive and bright subjects. In order to achieve a goal, a means to achieve it is needed in the educational process. In the context of the emerging 4.0 revolution that requires learners to be proactive, to have a comprehensive understanding, to know how to apply what they have learned in real life. "Learning must go together with practice", must have professionalism in learning, must create a good habit of thinking, must be aware that learning is a lifelong job, "learning citizen". Resolution 29 - NQ / TW has identified:

"Continuing to strongly innovate teaching and learning methods towards modernity, promoting the activeness, initiative, creativity and application of knowledge and skills of learners, remedying the one-way communication, passive memorization. Focusing on teaching ways of learning, thinking, encouraging self-study, creating a basis for learners to update and renew their knowledge, skills, and capacity development. Moving from studying mainly in the classroom to organizing diverse learning forms, paying attention to social activities, extracurricular activities, scientific research. Promoting the application of information technology and communication in teaching and learning” (Communist Party of Vietnam, 2013: 128-p.129).

Applying the above perspectives to innovating the university teaching methods to meet the needs of learners in the model of "learning citizens" is to teach students how to self-study and self-seek knowledge. University lecturers are instructors, suggesting, creating problem situations that encourage learners' exploration and discovery. The innovation of university teaching methods must go together with the renewal of the way of assessing learning results, promoting thinking, creativity, and teamwork. The assessment of student learning needs to innovate in the direction that the school and faculty can use different types of tests, such as short test, surprise test, homework, attendance design projects or projects, scientific research reports, essays, mid-semester exams; pay attention to strengthen the test of applicable type, analyze, synthesize and evaluate... make learners pay attention to reasoning, researching, analyzing and solving problems more often.

Today, Vietnam is transforming to approach the fourth industrial revolution, with the miraculous and powerful changes in science and technology, the innovation of university training activities meets the needs of learners. According to the model of "learning citizen", it will create an important turning point in the development of Vietnamese universities. Renovating university training activities to meet the needs of learners under the model of "learning citizen" in Vietnam in recent years creates a fundamental change in educational philosophy, affirms the value of education. University is knowledge construction. Innovating university training activities to meet the needs of learners according to the model of "learning citizen" is to innovate teaching methods with various forms towards integrating capacity development, focusing on specific problems, and vague problems should be avoided. 
In the model of "learning citizen", learners hold a central position to both approach and construct knowledge. Learning goals are not just learning to know but learning to do and learn to be creative; have enough capacity to think, especially creative thinking, adapting and coping with the rapid changes of society. From there, learning and working capacity with the superiority of information and communication technologies will strongly support the development of the "learning citizen" model in a learning society this is the dialectical action of things. Modern and open space is an important condition for people to be able to access knowledge from many sources without much cost. Learners have the advantage to connect the known and unknown, between traditional and modern, between real and virtual to choose appropriate, forming new knowledge and skills to suit their work needs.

Renovating university training activities needs to diversify training types to suit social needs according to the model of "learning citizens". These are considered practical and breakthrough solutions to promote the development of higher education, and universities often associate with enterprises in introducing students to practice and improve career skills and looking for jobs after graduation. The cooperation between the school and business not only creates "output" for training products, enlist the support of businesses but also captures required information from enterprises with management and advanced technology, creating a basis for innovation and adjustment of training objectives to meet the diverse requirements of a newly formed labor market. In the university training process associated with the needs of businesses and the labor market; shifting from training what the school has to the goal of training what society needs with the spirit of close connection between business and university. At the same time, continue to promote the innovation of content, curriculum and methods of teaching. Regarding the content of education towards the development of skills, expertise and ethical qualities of learners in order to serve the goal of socio-economic development in each specific historical period in general, to restore case of industrialization and modernization process in particular; Regarding the educational method, it must be directed to learners who are the center, helping learners to switch from studying and solving problems to discovering and applying modern knowledge, specifically: For general education, ensure that all people of school-age go to school; focus on developing intellectual, physical, forming quality, civic capacity, discovering and fostering aptitude, career orientation for students in accordance with the specific characteristics of the Vietnam. For the vocational education system, to rapidly increase the scale of vocational college and vocational secondary training for industrial parks, motivational economic regions and labor export; expand the network of vocational training institutions, develop district vocational training centers; improve the educational level, skill level, discipline and ethical qualities of employees. At the same time, the Vietnam needs to focus on training skills and expertise for workers, based on the actual needs of each different locality in the Vietnam, through the forms of self-training and training affiliate programs. For higher education, to focus on training qualified laborers suitable to the process of economic restructuring.

With that, universities need to actively cooperate at home and abroad, cooperate with businesses in implementing training programs; organize cooperation programs for short and long-term training for students and lecturers from one to three months, to complete university and master's knowledge with a number of universities in the world. Organizing a number of studies abroad semesters, short and long term, creating 
conditions for students to integrate in order to be able to exchange academically, find scholarships and create jobs after graduation.

Combine university training experiences to meet the needs of learners under the model of "citizenship learning" in some countries, from 2017 to now, the Ministry of Education and Training has guided the university system in the country to the university training thinking innovation, promoted rights and responsibilities of citizens. Lifelong learning is both a right and a responsibility of citizens. Citizens have the right to choose a form of study suitable to their capacity, interests, conditions and circumstances in order to improve their knowledge and understanding, and to meet the requirements of the period of renewal and international integration; study for a career, have a job effectively, to better meet the requirements of the job; learn to devote more, to make yourself and everyone happy; study to contribute to the development of the country and humanity. The Ministry of Education and Training also has many solutions to building a strong higher education system, providing a solid framework for sustainable human resource development, thereby creating economic growth, social welfare and encouraging individuals to pursue learning opportunities at all stages of their lives.

\section{Conclusion}

The Communist Party of Vietnam always determines people as the center and driving force for development. Renovating university training to meet the needs of learners according to the model of "learning citizen" is an effective way to take care of people's spiritual and material life.

In order to ensure that sustainable development, university training innovation to meet the needs of learners in the "learning citizen" model is an important contribution to building and improving the quality of common resources for develop and improve the socio-economic environment for the community, change the cultural face of the community and improve the quality of life of the people. Developing the "learning citizen" model, each individual's ability to adapt, integrate and develop personality will be enhanced. For sensitive objects, such as girls, women, ethnic minorities, ... the "learning citizen" model means a lot in supporting opportunities, creating motivation, helping them learn to update their knowledge, skills, improve labor productivity, generate more income, improve quality of life, change their status and social status, contribute to creating equality and better.

In order to develop education both now and in the future, renewing the model of "learning citizen" is the foundation and core, in which building learning opportunities throughout the region is both a guideline, a solution and the goal of education. This means that it is necessary to build a system of higher education so that any citizen who has a learning need will find favorable learning opportunities, suitable to the conditions and circumstances in different time and space Building a model of "learning citizen", creating lifelong learning opportunities is an inevitable trend, an epochal goal of all education in the world.

\section{References}

Charles C. Bonwell and James A. Eison (1991). Active Learning. Retrieved from https://files.eric.ed.gov/fulltext/ED336049.pdf. 
Communist Party of Vietnam (2011). Document of the XI National Congress of Delegates. National Political Publishing House.

Communist Party of Vietnam (2013). Document of the Eighth Conference of the XI Central Executive Committee. Party Central Office.

David E. McNabb (2009). Research Methods for Political Science. First published 2013 by M.E. Sharpe Armonk - New York, London - England.

David R. Shans, Riachard J. Duney and John D. McCarthy (2002). A retest of probability and reasonable choice. Journal of behavioral decision making. Retrieved from https://onlinelibrary.wiley.com/doi/abs/10.1002/bdm.413.

Donatella della Porta, Michael Keat (2008). Approaches and Methodologies in the Social Sciences, (C) Cambridge University Press. Retrieved from www.cambridge.org/9780521883221.

Hunsen, T. (1974). The Learning society. London: Methuen.

Jacques Delors-Learning: The Treasure within. Report to UNESCO of the International Commission on Education for the Twenty-first Century. UNESCO, 1996.

Knottnerus, J. David; Guan, Jian (1997). The Works of Peter M. Blau: Analytical Strategies, Developments and Assumptions. Sociological Perspectives, 40 (1): 109-128. doi:10.2307/1389495. ISSN 0731-1214. JSTOR 1389495.

Pham Cong Nhat (2014). Reform higher education towards international integration in our country today. Retrieved from http://tapchicongsan.org.vn/web/guest/chi-tiettim-kiem/-/2018/30373/\%C4\%91oi-moi-giao-duc-\%C4\%91ai-hoc-theo-huonghoi-nhap-quoc-te-o-nuoc-ta-hien-nay.aspx.

Pham Tat Dong (2019). Learning society and learning citizen. Retrieved from https://moet.gov.vn/giaoducquocdan/giaoducthuongxuyen/Pages/default.asp $\mathrm{x}$ ?ItemID=6127

Schon D. A. (1973). Beyond the Stable State. Public and private learning in a Changing Society. Hormonds words worth: Penguin

Tobias Andersson (2016). Rationality in educational choice - A study on decisionmaking and risk-taking in academic settings. Retrieved from http://www.divaportal.org/smash/get/diva2:945136/FULLTEXT01.pdf 


\section{Creative Commons licensing terms}

Author(s) will retain the copyright of their published articles agreeing that a Creative Commons Attribution 4.0 International License (CC BY 4.0) terms will be applied to their work. Under the terms of this license, no permission is required from the author(s) or publisher for members of the community to copy, distribute, transmit or adapt the article content, providing a proper, prominent and unambiguous attribution to the authors in a manner that makes clear that the materials are being reused under permission of a Creative Commons License. Views, opinions and conclusions expressed in this research article are views, opinions and conclusions of the author(s). Open Access Publishing Group and European Journal of Social Sciences Studies shall not be responsible or answerable for any loss, damage or liability caused in relation to/arising out of conflicts of interest, copyright violations and inappropriate or inaccurate use of any kind content related or integrated into the research work. All the published works are meeting the Open Access Publishing requirements and can be freely accessed, shared, modified, distributed and used in educational, commercial and non-commercial purposes under a Creative Commons Attribution 4.0 International License (CC BY 4.0) 